Olgierd Sebastian Nowak

https://orcid.org/0000-0002-4317-5754

Nicolaus Copernicus University in Toruń, Poland

\title{
Homo sum, humani nihil a me alienum puto1 - the imperative of the principle of humanitas in views on slavery derived from natural law. M.T. Cicero's views on the subject of slavery and slaves
}

\author{
"Meminerimus autem etiam adversus infimos iustitiam \\ esse servandam. \\ Est autem infima condicio et fortuna servorum" ${ }^{2}$
}

M.T. Cicero, De officiis

\begin{abstract}
The phenomenon of slavery existed throughout the entire period of the ancient world and met with interest from both Greek and Roman philosophers. Despite the emerg-

M.T. Cicero, De re publica. De legibus 1,12,34, translated by I. Żółtowska, O państwie. O prawach, Warszawa 2010, Hachette, p. 162; M.T. Cicero, De re publica. De legibus. De officiis. De virtutibus. Text Publishing house Teubner. Edition maior, Lipsk 1949, translated by W. Kornatowski, Pisma filozoficzne. O państwie. O prawach. O powinnościach, O cnotach, second vol., Warszawa 1960, PWN; Publiusz Terencjusz Afer, Samoudręczyciel, verse 77, in: M.T. Cicero, De legibus 1,12,34, Op. cit.; L.A. Seneka, Epistulae morales ad Lucillium 95,53, translated by W. Kornatowski, Warszawa 1961, PWN, p. 104.

M.T. Cicero, De Officiis 1,13,41. "Next, let us remember that the principles of justice must also be observed towards people of the lowliest rank. The lowest condition is that of slaves affected by the hardest plight", translated by W. Kornatowski, Warszawa 1960, PWN, p. 349.
\end{abstract}


ing views of various philosophers criticizing slavery as a social phenomenon, no theory of slavery was formulated then. The philosopher who-, in both his works and correspondence, included numerous references to the situation of slaves and the institution of slavery was M.T. Cicero. Searching for humanism in Cicero's views on the abovementioned issue, attention was drawn to the principles of the Stoic doctrine, within which the concept of human freedom was formulated, and to the essence of natural law. These concepts made it possible to analyse the discussed problem in the context of the words of Terence Homo sum, humani nihil a me alienum puto. And as regards humanism in Cicero's views, it is evident when he recognizes a human being in a slave; when he says that the principles of justice must be observed towards people from the lowest rank, which is the rank of slaves; when he firmly states that slavery is among the worst things that can happen to the human being. On the other hand, we see Cicero's completely different views on slaves when he talks about punishing slaves, „keeping a tight rein on them," or „destiny by nature for the best to rule others, and with great benefit for weaker beings"; also when he emphasizes his negative attitude towards the liberation of slaves. To conclude it should be emphasised that this characteristic feature of Cicero, namely his lack of uniformity of views on various philosophical doctrines, which we can also find in his views on slavery and the rank of slaves, does not prevent us from seeing a humanist in Cicero who, with his sense of justice, advocating the stoic doctrine and the principles of natural law, moved very slowly towards the stoic moral philosophy and all the ethical principles that Christianity would bring.

\section{Keywords}

Marcus Tullius Cicero, philosophical works, speeches, Cicero's letters, philosophy, law of nature, natural law, Roman Republic, slavery, slave status, humanism, humanity, justice, humankind, social bond, stoic doctrine, ethics, aesthetics, sources of law.

\section{The views of ancient Greek philosophers on slavery as a socio-legal phenomenon in the 5 th- 4 th centuries BC}

The issues falling within the subject matter of this article should be preceded by a few remarks on the social phenomenon of slavery; the phenomenon accompanying the history of the ancient world from the beginning until its fall, 
which we can study, read about and analyse. ${ }^{3}$ Although economic and political relations changed, monarchies collapsed, and democracies replaced them, which later transformed into tyrannies or oligarchies, slavery, as a social phenomenon associated with the ancient world, invariably existed because it was too deeply rooted in the political systems of the states of the ancient world. If there was any problem regarding slavery, it was, as B. Bolz rightly argues, a purely practical problem, hence there were no ancient studies on the theory of slavery, as well as the "philosophy of ancient slavery." ${ }^{4}$ However, it should be noted that slavery which existed in both Greece and Rome caused reactions from philosophers who either accepted it in their doctrines or condemned it as a major problem for societies and states.

If we do not find any philosophical works on the phenomenon of slavery produced by the philosophers living at the turn of the 5 th and 4 th centuries BC, such as Socrates or Democritus, or any of their words of criticism of the then-established views on slaves and slavery, and if in the 4th century BC, the thesis of the existence of „slavery by nature" prevailed, then, at the same time the opposite theories emerge, emphasizing the equality of people. But an extremely important feature of these new philosophical views is lack of postulates aimed at abolishing this phenomenon. The philosophers who defined more closely the discrepancy between natural law and statute law were sophists. Particular attention should be paid to Alkidamas of Elaea, a philosopher living in the 4th century B.C.E., who taught that "statute law prescribes what is prohibited by natural law and prohibits what natural law prescribes"; he advanced the thesis that there is no natural division between free people and slaves because God created everyone free and nature did not make anyone a slave. ${ }^{6}$

However, without entering into the analysis of the doctrines developed by philosophers of the early period of ancient Greece, for whom slavery was a natural phenomenon and necessary for the normal life of the citizens of a given

${ }^{3}$ I. Bieżuńska-Małowist, M. Małowist, Niewolnictwo, Warszawa 1987, Czytelnik, p. 8 and p. 214; H. I. Finley, Ancien Slavery and Modern Ideology, 1980.

B. Bolz, Niewolnicy w pismach Cycerona, Poznań 1963, PAN, p. 11.

Arystoteles, Retoryka 1398 b, translated by W. Madyda, Wrocław 1953 - first edition; Wrocław 2006 - second edition, Zakład Narodowy im. Ossolińskich.

${ }^{6}$ I. Bieżuńska-Małowist, M. Małowist, Niewolnictwo, Op. cit., p. 225; T. Giaro, Wolność i niewola, in: Prawo rzymskie. U podstaw prawa prywatnego, Warszawa 2009 - first edition, 2014 second edition, PWN, p. 189; R. Tokarczyk, Klasycy praw natury, Lublin 2009, Wydawnictwo Uniwersytetu MCS, p. 46; Arystoteles, Retoryka 1373 b, Op. cit. 
city-state, and preceding the stoic views on slavery with Plato and Aristotle's look at the above phenomenon, it should be noted that both Plato and Aristotle believed that some people are slaves by nature, while others are created to rule and govern. ${ }^{7}$ Nevertheless, Plato considered slavery to be a necessary evil because from the point of view of natural law ${ }^{8}$, slaves are not always intellectually and morally lower in a social hierarchy. Therefore, he recommended alleviating this pitiful necessity by reason and justice. ${ }^{9}$ Moreover if we consider Plato and Aristotle to be supporters and propagators of the theory of the "naturalness" of the institution of slavery, we can still see some doubts about this institution in Aristotle's doctrine, when he says that „the power of the master over slaves is against nature, because only by law one is a slave and the other is free, and by nature there is no difference between them. That is why (this state of affairs) it is not fair, because it is based on violence". ${ }^{10}$ However, Aristotle, sustaining his theory about slaves by nature and their lack of ability to reason and think independently, states: "I must (...) admit that there are people, some of whom are slaves everywhere, and others nowhere."

\section{The notion of equality of human beings contained in the doctrine of the creators of the Stoic School and Middle Stoa}

These early progressive ideas of equality of people by birth were adopted and disseminated by philosophers and writers of the Hellenistic period, and then by writers living the times of the Roman Republic and the Empire. In the propagated ideas of striving to achieve the perfection of virtue, that is, a virtue consistent with nature, philosophers did not deal extensively with social issues that

${ }^{7}$ I. Bieżuńska-Małowist, M. Małowist, Niewolnictwo, Op. cit., pp. 230-234.

B. Bolz, Niewolnicy w pismach Cycerona, Op. cit., p. 15.

9 Platon, Politeia V 469 b, c, translated by W. Witwicki, Państwo, Warszawa 1999, Wydawnictwo Alfa.

10 Arystoteles, Polityka I, II, 1253 b; 1255 a, translated by L. Piotrowicz, Wrocław 1953 - first edition, Wrocław 2005 - second edition, Zakład Narodowy im. Ossolińskich; I. Bieżuńska Małowist, Niewolnictwo, Op. cit., pp. 222-223; Arystoteles, Retoryka 1398 b, Op. cit.

${ }^{11}$ Arystoteles, Polityka 1255 a, translated by L Piotrowicz, Op. cit.; I. Bieżuńska-Małowist, M. Małowist, Op. cit., p. 224. Particularly noteworthy is Aristotle’s famous saying in Nicomachean Ethics, that "a slave is a living tool and a tool a dead slave”, Etyka Nikomachejska, translated by D. Gromska, Warszawa 1982, PWN. 
would result from a contract, not from nature. Thus, if we look at the views of the founders of the Stoic school, namely Zeno and Chrysippus, we will notice that, according to their doctrine, external differences between people, i.e. between Greeks and barbarians, free people and slaves, result from chance and not from the laws of nature. ${ }^{12}$ Attention should also be paid to the notion of freedom in the doctrine of the first Stoics, particularly to that of Epictetus; the concept that will occupy an important place also in the doctrine of Epictetus and Seneca, and which will later be elaborated in the works of Roman jurists. If the earlier doctrines did not consider the issue of human freedom, taking it for granted and assuming that human beings are characterized by their ability to choose freely and that even in the face of omnipotent gods they have freedom of action ${ }^{13}$, the stoics, especially Chrysippus, were the first to address the issue of freedom, and therefore they took up the issue of freedom as a problem, which gave rise the question of a place for human freedom. ${ }^{14}$ Although God, according to the Stoics, bears full responsibility for everything that happens in the world, the Stoics argued that the freedom that determines human dignity means controlling our own actions". Cicero raises the issues of freedom, destiny, consent, eternal reasons in De fato $(2,18,42 ; 2,19,43)$, maintaining, that „(...) everything that happens has its previous cause (...)". ${ }^{15}$ Advocating the brotherhood of all people of the world and describing themselves as citizens of the world, they saw real freedom in the wisdom of the stoics, independent of desires and superstitions. According to the theory understood in this way, only the sage was free, while most people were in slavery. Freedom was also measured in terms of good and evil. Hence, according to the Stoic philosophy, „bad people are slaves," „it is unimportant whether someone has the status of a slave or a free person", ,a sage is not obliged to act in support of improving the existing social relations. ${ }^{36}$ Understanding the concept of true freedom in this way, at the same

12 R. Tokarczyk, Klasycy praw natury, Op. cit., pp. 78-111; L. Strauss, Prawo naturalne $w$ świetle historii, translated by T. Górski, 1969, Instytut Wydawniczy PAX, p. 127.

13 J. Jarzębiak, Jak możliwa jest wolność? Odpowiedź Chryzypa z Soloi, „Przegląd Filozoficzny - Nowa Seria” R. 14 (2005) nr 2 (54), p. 68.

${ }^{14}$ J. Jarzębiak, Jak możliwa jest wolność?, Op. cit., p. 68.

15 M.T. Cicero, De fato 2,18,42; 2,19,43, translated by W. Kornatowski, O przeznaczeniu, Warszawa 1960, PWN, p. 428.

${ }^{16}$ I. Bieżuńska-Małowist, M. Małowist, Op. cit., pp. 230-234; St. Stabryła, Przedmowa do Myśli Seneki. „Therefore, all that is good or bad in human beings depends only on them., Kraków 1987, Wydawnictwo Literackie, p. 15. 
time they tolerated the existence of slavery, perhaps they did not fully accept it, but they did not promote its abolition.

But the stoic idea of attributing the ability to be a free person only to sages and emphasizing the need to improve oneself in order to achieve absolute freedom allows us to notice that that despite in their doctrine there are assumptions of the stoic equality of all people in the cosmopolitan state, the stoics accepted the diversity of society in terms of mental perfection, the ability to lead an independent existence, innate abilities and all other virtues. Hence, in the early developments of the Stoic doctrine, we see the philosophers speaking in favour of elitist class solidarity of slave owners for whom the lower classes of society were incapable of independent existence. ${ }^{17}$ Zeno and Chrysippus's doctrine, which is the expression of both philosophical and materialistic views on social issues, was to serve the Hellenistic monarchy, and subsequently introduced to the Roman soil through the intermediary of Panaitios and Poseidonios, it would serve the Roman Republic, in which the position of the rich Romans was rapidly growing, with hundreds of slaves at their disposal. Slavery, as a consequence of the lost laws of nature, was accepted, as a specific approach to matters and events beyond the human being's control, and therefore it should be accepted stoically. ${ }^{18}$

With regards to the cited Stoic doctrine from the time of Old Stoic School, attention should be paid to the position of Panaitios, who recognized that slaves are, after all, mentally and intellectually handicapped, and therefore they require to be subjected to a governing authority. On the other hand, Panaitios pointed to the possibility of replacing the slave's work with some other form of work, e.g. as domestic service, which might have been a forecast of some actions undertaken to improve the situation of slaves. However, indifferent attitudes towards slavery would still prevail in the philosophy of the first Stoics, and their doctrines will lack any attempts to promote the rejection of slavery as an institution violating human dignity.

17 J. Legowicz, Historia filozofii starożytnej Grecji i Rzymu, Warszawa 1986, PWN, pp. 369-370.

18 D. Laertios, Żywoty i poglądy słynnych filozofów VII,1,118-119, translated by I. Krońska, Warszawa 1968 - first edition, 1988 - second edition, PWN, p. 423; L. Strauss, Prawo naturalne w świetle historii, Op. cit., p. 145. 


\section{Slavery as a social phenomenon in the last years of the Roman Republic. The legal regulation of the status of slaves}

These first stoic doctrines on slavery would develop towards promoting the humane treatment of slaves, alleviating their social and legal situation as the stoic doctrine took hold in Rome. It should be noted, however, that this phenomenon and its significance underwent numerous transformations from the economic and social point of view prevailing in Ancient Rome. The phenomenon reflected in all its problems and changes in the legal situation of slaves became most noticeable in the last centuries of the Roman Republic and in the first centuries of the empire, i.e. from the 1 st century $\mathrm{AD}$ until the $3 \mathrm{rd}$ century $\mathrm{AD}$, which means during the period of greatest development of the Roman state and its legal system. ${ }^{19}$

Regulating the status of slaves and the rights of owners in the late republic was extremely important, due to the increasing number of slaves in the Roman state, especially in the rein of Caesar's, and in connection with his conquests, when about two-thirds of all slaves were recruited from prisoners. The conquest of Gaul itself (58-50 BC) gave Rome about a million slaves, and it should also be pointed out Rome obtained slaves from border fights and from pirates involved in trading people ${ }^{20}$. In addition, legal regulations allowed for an increase in the number of native slaves by introducing the right of inheritance, which in turn contributed to the greatest possible security of the interests of slave owners. Roman law understood slavery as an institution of the law of nations (ius gentium), contrary to natural law, which is regulated by Justinian in Institutiones: "Slavery is an institution of the law of nations, through which, contrary to nature, someone is put under the authority of another person who is an owner" $(\mathrm{I} .1,3,2) .{ }^{21}$ Because the Roman state during the formation of slavery acts as a free state (literally, free city) (civitas libera), in which freedom is the supreme and immutable right of citizens (eximium ius et ius illibatum), all resolutions of the

${ }^{19}$ K. Kolańczyk, Prawo rzymskie, updated by J. Kodrębski, Warszawa 2007, Lexis Nexis, p. 188.

${ }^{20}$ K. Kolańczyk, Prawo rzymskie, Op. cit., p. 186; W. Kornatowski, Zarys dziejów myśli politycznej starożytności, Warszawa 1968, Instytut Wydawniczy PAX, pp. 197, 249-250, 352-353; H. Olszewski, M. Zmierczak, Historia doktryn politycznych i prawnych, Poznań 1993, Ars boni et aequi, pp. $40-44$.

${ }^{21}$ (I. 1,3,2) Institutiones Iustiniani, translated by C. Kunderewicz,Warszawa 1986, PWN, p. 20 . 
highest state authority summa potestas populi ${ }^{22}$, „quod populus iubet atque constituit" ${ }^{23}$ do not apply to slaves as it is a law which "each nation established for themselves, it is relevant exclusively to them and is called civil" (G.1,1), and the nation is a population of free citizens $(\mathrm{G} .1,3)^{24}$. Furthermore, the criminal justice system of the state courts of law (iudicia publica) did not apply to slaves. Slaves belonged to their owners. This position was adopted by The Act of XII Tablic (tabl. 8,3,44) and lex Aquilliae (D. 9,2,2 25, which, according to Gaius, equated slaves with four-legged animals, such as: "sheep, goats, cattle, horses, mules, donkeys ${ }^{26}$. Thus, the Act eliminated slaves from legal and public relations, pushing them onto the margins of the Roman nation because during the republic the concepts of nation and state were the same: res publica and populus Romanus, and therefore only a Roman citizen could be a member of the Roman nation: "populi appellatione universi cives significantur" (,the name of the nation designates all citizens"). ${ }^{27}$

The slave system, on the basis of which the power of Rome was founded and developed, existed under certain legal norms that sanctioned the system and its existing legal devices, and the legal situation of every human being in the Roman state was determined, among others, by status libertatis, which decided about the state of freedom or slavery. ${ }^{28}$ Status libertatis of the population of Rome was unequivocally determined by Gaius, a jurist of the 2 nd century $\mathrm{AD}$, in $\mathrm{In}$ stitutiones (G. 1,9), stating: „And the most general division concerning the right of persons is that all people are either free or not free". ${ }^{29}$

${ }^{22}$ M.T. Cicero, De re publica 1,47, translated by W. Kornatowski, Warszawa 1960, PWN, p. 44.

Gai Institutiones 1,3 („the law is what the people command and decide”), translated by C. Kunderewicz, Warszawa 1982, PWN, p. 29.

24 (G. 1,1; G. 1,3) Gai Institutiones, Op. cit., pp. 28-29.

25 (D. 9,2,2) Digesta Iustiniani, edited by T. Palmirski, Kraków 2013, 2014, Wydawnictwo Poligrafia Salezjańska, p. 305.

26 B. Łapicki, Poglądy prawne niewolników i proletariuszy rzymskich, Łódź 1955, Zakład im. Ossolińskich, Wrocław, pp. 48-49; T. Giaro, Wolność i niewola, in: W. Dajczak, T. Giaro, F. Longchamps de Berier, Prawo rzymskie. U podstaw prawa prywatnego, Op. cit., p. 189.

7 (G. 1,3), Gai Institutiones, Op. cit., pp. 28-29; B. Łapicki, Poglady prawne..., Op. cit., pp. 49 and 51.

${ }^{28}$ K. Kolańczyk, Prawo rzymskie, Op. cit., p. 181.

${ }^{29}$ (G. 1,9) Gai Institutiones, Op. cit., pp. 30-31. 
In this one sentence, starting the lecture on personal law by Gaius, we receive an indisputable division of the population and their rights, but at the same time the quintessence of the Roman state system and acceptance of the slave system.

\section{Marcus Tullius Cicero's humanism in views on slavery and slaves, derived from natural law}

In such a legal and social system, in the last years of the Roman Republic, Marcus Tullius Cicero, a member of a moderately rich family of equites, was destined to live. He was a philosopher, politician, senator, consul, a man who shaped the political history of Rome, a citizen of Rome who owned many estates, including familia rustica, which is estimated to have had around 100 slaves, engaged mainly in farming, husbandry and pasturage. It certain that his familia urbana was considerably smaller, the size of which we have no further information about, but one could assume, as noted by B. Bolz, that part of his familia urbana, engaged in domestic service, numbered at least several dozen people $e^{30}$, and, moreover, we need to take into account those slaves who, due to their education, were closely attached to Cicero and worked as his writers, readers and secretaries. Thus, if Cicero's financial status allowed him to be part of a group of two thousand richest Romans, it proves that as a person living in a certain system, he found himself perfectly in the slave system of Rome. What is more, he could not imagine getting rid of slaves, which he mentions in In Pisonem, saying that "the very idea of disposing of your own slaves would have to regarded as a sign of dangerous madness." ${ }^{31}$

Only after situating Cicero in certain socio-political realities of the Roman Republic, can we consider the issue of Cicero's views on slavery and slaves, bearing in mind his ethics, firmly rooted in Stoic philosophy, and then we can search for the idea of humanitas in Cicero's view on the phenomenon of slavery in Rome.

It should be stressed that the essence of Cicero's humanism in his views on slavery stems from the law of nature, because, as Cicero notes: „(...) a man

30 B. Bolz, Niewolnicy w pismach Cycerona, Op. cit., pp. 30-32; K. Kumaniecki, Cyceron i jego współcześni, Warszawa 1954, Czytelnik, pp. 23-28.

${ }^{31}$ M.T. Cicero, In Pisonem 20,48. 
obedient to nature is not able to harm others.” („Ex quo efficitur, hominem naturae oboedientem homini nocere non posse"). ${ }^{32}$

Cicero gives us a lecture on the law in De legibus, which is based on the Stoic philosophy. In the first book of this work we find Cicero's view on the essence of law, the source of law and its foundation. As early as in the first sentences of the treaty Cicero says that in order to clarify the essence of law, it must be derived from human nature ${ }^{33}$, stating that: "If they were guided by the principle according to which (as the poet says) I am human, I consider nothing human alien to me, everyone would equally respect the law” („Quodsi, quo modo $s<u n>t$ natura, sic iudicio homines 'humani, ut ait poeta, nihil a se alienum putarent', coleretur ius aeque ab omnibus".) ${ }^{34}$ Whereas, in the second book, referring to the essence of natural law, he proceeds to discuss the Roman legal system.

Pointing to those elements that the law should take into account, Cicero simultaneously notices that the law should be derived not from the praetorian edicts, which in Cicero's time were an important source of law, nor from the Act XII Tablic, but from the philosophy of law, which will allow to determine the essence of law in connection with human nature. ${ }^{35}$ Hence, we find in Cicero a clear reference to natural law when he says that "the greatest scholars began with natural law."

M.T. Cicero, De legibus 1,5,18

„Igitur doctissimis uiris proficisci placuit a lege, haud scio an recte, si modo, ut idem definiunt, lex est ratio summa, insita in natura, quae iubet ea quae facienda sunt, prohibetque contraria. Eadem ratio, cum est in hominis mente confirmata et $<$ per $>$ fecta, lex est." ${ }^{36}$

According to Cicero, the law, therefore, is wisdom, but combined wisdom, combined with such human thinking that will cause the law to be shaped in such

32 M.T. Cicero, De officiis 3,5,25,26, Pisma filozoficzne: O państwie. O prawach. O powinnościach. O cnotach. translated by W. Kornatowski, second vol., Warszawa 1960, PWN, p. 482.

33 M.T. Cicero, De legibus 1,5,17, Op. cit., p. 154.

${ }^{34}$ M.T. Cicero, De legibus 1,12,33, Op. cit., p. 162; Publiusz Terencjusz Afer, Samoudręczyciel, verse 77.

35 M.T. Cicero, De legibus 1,5,17, Op. cit., p. 154.

36 M.T. Cicero, De legibus 1,5,18, Op. cit., p. 154. 
a way that it will have the power to require proper conduct, but at the same time it will prohibit any bad behaviour which is contrary to the provisions of law.

If Cicero's natural law is the wisdom itself and the result of the human being's reasonable actions, he at the same time notices that statute law should be derived from natural law, which was created before the emergence of states. Cicero bases his justifications as to the necessary compliance of natural law with statute law on the statement that „(...) all nature depends on the power of immortal gods, on their eternal attributes, prudence, power, reason, will (...) ${ }^{{ }^{37} 7}$ the gods who endowed him with reason, which constitutes a bond between human beings and gods. It is from the existing bond of reason, which is the natural link between human beings and gods, that Cicero derives a sense of justice, which reveals itself to people as natural law, and what is more, it is from this natural law, linking humans and gods, and statute law, originating from it, that Cicero derives a stoic view on the universe, gods and people..$^{38}$ It is from the divine being that Cicero derives humans' valour, but also the possession of the senses and abilities of the human body and the constant development of their minds, their ability to reason..$^{39}$

Cicero summarizes his introduction to the essence and sources of law by saying: " $(. .$.$) the humankind came into existence in order to cultivate justice, and$ the law was not established by the decision of humans, but it is an element of natural order $(\ldots)^{\prime 40}$, moreover, he remarks that although people differ in their ability and the skill to acquire knowledge, there are no differences between individuals within a species; and therefore humankind constitute a cohesive community.

The words of Terence, who was a slave, freedman and poet, quoted above: "Homo sum, humani nihil a me alienum puto" ${ }^{41}$, which M.T. Cicero invokes in the first book of De legibus, are somehow the basis of his lecture on natural law. Thus, the way the natural law is conceived by Cicero provides the basis for his humanism and his views on slavery.

\footnotetext{
37 M.T. Cicero, De legibus 1,7,21, Op. cit., p. 156.

${ }^{41}$ L.A. Seneka, Epistulae morales ad Lucillium 95, 53, Op. cit., p. 104.
} 


\section{The concept of humanity in M.T. Cicero's doctrine as the reflection of the stoic principles}

Therefore, let us look at what Cicero's attitude to the phenomenon of slavery in Rome was like, which we can see both through his doctrine and the analysis of Cicero's writings. Let us look at this issue in the context of Cicero's words stating that it does not matter how we define mankind because ,each definition applies to everyone, and this is a sufficient proof that within the species there are practically no differences between individuals; if there were one formula, it would not cover all." ${ }^{42}$

This issue should be looked at by separating Cicero's views included in court speeches and philosophical works from the views formulated by Cicero in the letters addressed to his family and friends, from which we obtain information about slaves belonging to the familia urbana, particularly those slaves with whom Cicero had closer contact due to their duties performed directly for and around him, and in particular we should carefully look at the letters written by Cicero to the slave of Tiro, who performed a number of functions directly around Cicero, a slave who was irreplaceable not only in matters related to Cicero's work, but also in financial ones.

As regards the Stoic ethics and its impact on Cicero's humanism and the moral principles of this doctrine, one should pay particular attention to the work titled De officiis, which grew against the background of a specific political, social and ideological situation of the Roman Republic. ${ }^{43}$ De officiis is a collection of moral directives and regulations, talking about human responsibilities; attention should be paid to this work in the context of this article because we see in it a clear touch of compassion for slaves, especially when Cicero states that the principles of justice should be observed towards the people of the lowest rank, which is the rank of slaves. Furthermore, Cicero claims that good advice is given by those who recommend treating slaves as mercenaries and paying them for their work: „(...) qui ita iubent uti, ut mercennariis, operam exigendam, iusta praebenda (...)." ${ }^{34}$

${ }^{42}$ M.T. Cicero, De legibus 1,10,29; 1,10,30, Op. cit., p. 160

A. Nawrocka, „De officiis” Cycerona i ”De officiis Ministrorum” Św.Ambrożego. Problem recepcji etyki Cycerona w etyce chrześcijańskiej Św. Ambrożego. Studia Antiquitatis Christianae, vol. eith, Warszawa 1988, Akademia Teologii Katolickiej, pp. 19-26.

44 M.T. Cicero, De officiis, Pisma filozoficzne 1,13,41, Op. cit., p. 349. 
M.T. Cicero, De officiis 1,13,41

41]"Meminerimus autem etiam adversus infimos iustitiam esse servandam. Est autem infima condicio et fortuna servorum, quibus non male praecipiunt, qui ita iubent uti, ut mercennariis, operam exigendam, iusta praebenda. Cum autem duobus modis, id est aut vi aut fraude, fiat iniuria, fraus quasi vulpeculae, vis leonis videtur; utrumque homine alienissimum, sed fraus odio digna maiore. Totius autem iniustitiae nulla capitalior quam eorum, qui tum, cum maxime fallunt, id agunt, ut viri boni esse videantur. De iustitia satis dictum." ${ }^{35}$

In the quoted fragment of the work, Cicero clearly condemns the deception and violence used against a human being, particularly when people commit such acts trying to be seen and regarded as fair-minded. In Cicero's approach to the issue of paying slaves for the work done, and thus treating them as mercenaries, we see a certain convergence of views with the earlier cited doctrine of Panaitios.

An analysis of the subsequent books of De officiis $(3,5,26)$ shows that $\mathrm{Ci}$ cero introduces the concept of humanity and injustice done to other people. He speaks especially expressly about it, when he states that "those who harm others to gain some benefit, they (...) act against nature" ${ }^{\prime 4}$, and then asks: „Si nihil existimat contra naturam fieri hominibus violandis, quid cum eo disserasqui omnino hominem ex homine tollat." ${ }^{37}$ These words are a kind of repetition but also a development of Cicero's earlier deliberations contained in book 3,5,23, when Cicero notes that "It is not for our own benefit to harm another." ${ }^{48}$

Moreover, continuing his deliberation of this issue, he states that nature itself commands human beings to willingly help others regardless of who they are, and only for the sake of their humanity, „because we are all subject to the same law of nature", which „f forbids us to harm the other human being” $(3,6,27)$ :

M.T. Cicero, De officiis 3,6,27

[27] „Atque etiam si hoc natura praescribit, ut homo homini, quicumque sit, ob eam ipsam causam, quod is homo sit, consultum velit, necesse est secundum eandem naturam omnium utilitatem esse communem. Quod si ita est, una continemur omnes et eadem lege naturae, idque ipsum si ita est, certe violare alterum naturae lege prohibemur. Verum autem primum, verum igitur extremum." ${ }^{.49}$

45 M.T. Cicero, De officiis 1,13,41, Op. cit, p. 349.

${ }^{46}$ M.T. Cicero, De officiis 3,5,26, Op. cit., p. 482.

${ }^{47}$ M.T. Cicero, De officiis 3,5,26: "If they suspect that by harming people they do nothing contrary to nature, how would you deal with someone who completely deprives others of their humanity?", Op. cit., p. 482.

${ }^{48}$ M.T. Cicero, De Officiis 3,5,23, Op. cit., p. 481.

49 M.T. Cicero, De officiis, Pisma filozoficzne 3,6,27, Op. cit., p. 483. 
Further in the third book $(3,6,28)$, Cicero maintains that it is absurd for people to claim that their attitude towards their father or brother is different from the one towards other citizens, that it is wrong of them to believe that "no right and no bond which aims at the general good connects them with other citizens", because such a view tears apart all coherence of the community which the state creates."

M.T. Cicero, De officiis 3,6,28 „(...) Qui autem civium rationem dicunt habendam, externorum negant, ii dirimunt communem humani generis societatem; qua sublata beneficentia, liberalitas, bonitas, iustitia funditus tollitur; quae qui tollunt, etiam adversus deos immortales impii iudicandi sunt.(...).".50

Analysing the above-mentioned excerpt from the third book, we notice Cicero's humanism, derived from the Stoic doctrine and applying to all human beings. Although in the quoted excerpts from the work, Cicero does not mention specific social ranks, or he does not say anything about slaves, his humanism applies to every person when he states that a person obedient to nature is not able to harm another. Through his works, Cicero introduces into the Roman society such concepts as: communitas hominum, corpus humanitatis, societas humani generis.

Cicero's view on the human being is almost identical to the above-mentioned excerpts from the first book of De Legibus 1,10,28; 1,10,30; a view full of humanism and stoic principles, which states that reason, which gives us an advantage over animals „(...) is a common feature of all people." ${ }^{51}$

We also perceive Cicero's humanism through his statements articulating a negative assessment of slavery as a condition in which every person can find oneself, regardless of whether one is wise, because wisdom alone does not protect anyone from misfortunes that can affect them.

If in Tusculanae disputationes $(5,10,29)$ he mentions various misfortunes that can happen to the human being, such as: poverty, disgrace, lowly descent, leaving friends, loss of loved ones, illness, loss of homeland, exile, then in the last place he mentions slavery, as if to emphasize all evil and hopelessness associated

50 M.T. Cicero, De officiis, Pisma filozoficzne 3,6,28 „On the other hand, those who admit that they must show consideration for their fellow citizens and refuse it only to foreigners destroy the general bond that connects all mankind; and after all, the removal of this bond completely eradicates charity, attentiveness, reliability and justice. Those who destroy them should be considered to be wicked also towards immortal gods". Op. cit., p. 483.

51 M.T. Cicero, De legibus 1,10,30, Op. cit., p. 160. 
with this condition. ${ }^{52}$ Thus, if in the next excerpt from the work he lists various bad things that can happen to a person, such as: "poverty, disgrace, disability, blindness", the thought of which can disturb the peace of even a sage and does not allow you to be happy, then again at the end he lists slavery, „which happens not only to individual people but also to powerful nations" ${ }^{33}$, and as if to emphasize its weight and all its evil, he asks whether one can be happy to expect to be enslaved?

Cicero gives a decidedly negative assessment of slavery and slaves in Philippicae, when he says: „Nihil est detestabilius dedecore, nihil foedius servitute”. (Philippica III,14,36) and when he also sates: „Non enim in spiritu vita est, sed ea nulla est omnino servienti”. (Philippica 10,20).

Cicero took a completely opposite position on slavery and slaves in the third book of De re publica, and also in De provinciis consularibus oratio, as well as in In Catilinam Oratio.

It seems that B. Bolz rightly observes that the most extensive disquisition on slavery as a social institution could be found in the third book of De re publica, which can be inferred from the preserved fragments. However, the author of this paper wishes to draw the reader's attention to $3,25,37^{54}$, when Cicero asks: "Do we not see that nature itself selects the best to rule others, and with a great benefit for weaker beings. (...) The owners tame slaves, like wisdom, the noblest part of the human spirit that struggles with its weaknesses - desire, anger and all the rest of this kind of disorders...." ${ }^{55}$ Furthermore, Cicero says directly that human spiritual weaknesses, like slaves, should be kept on a tight rein. However, from slavery understood in this way Cicero differentiates ,unjustified subordination", which occurs when those who remain under constraint could be masters of themselves, and yet they were enslaved..$^{56}$

The analysis of these excerpts from Cicero's work allows us to see the similarity of Cicero's views, with the doctrine of Aristotle, according to which „(...)

52 M.T. Cicero, Tusculanae disputationes 5,10,29, translated by E. Rykaczewski, Rozmowy tuskulańskie, Warszawa 2009, Wydawnictwo Hachette, p. 210; Tusculanae disputationes, translated by J.Śmigaj, Rozmowy tuskulańskie, third vol., Warszawa 1961, PWN.

53 M.T. Cicero, Tusculanae disputationes 5.6,15, Op. cit., p. 204.

${ }^{54}$ B. Bolz, Niewolnicy w pismach..., Op. cit., p. 86; M.T. Cicero, De re publica 3,25,37, translated by I. Żółtowska, Warszawa 2010, Hachette, Op. cit., pp. 108-109.

55 M.T. Cicero, De re publica 3,25,37, Op. cit., pp. 108-109.

56 M.T. Cicero, De re publica 3,25,37, Op. cit., p. 109. 
there are people, some of whom are slaves everywhere and the others are nowhere. ${ }^{57}$ In De provinciis consularibus oratio $(5,10)$, Cicero explicitly says that there are whole nations born to be enslaved "nationibus natis servituti”"58, and also other nations which can easily endure the state of slavery, which Cicero claims in Tusculanae disputationes 3,22,54., stating that: “(...) I was moved more by the sight of the Corinth ruins than by the Corinthians themselves who eventually got accustomed to their misfortune and hardened in pain." 59 In some of Cicero's speeches, we can see calls for solidarity among slave owners, as well as a demand for their loyalty to each other. He particularly explicitly speaks against the slaves in the trial against Catiline, recognizing him as ,the organizer and mastermind behind a criminal conspiracy, inciting slaves and ruined citizens to rebel." ${ }^{\prime 60}$ In an extremely sharp way he expresses his view on the subject of sanctions for slaves who commit crimes when he says: "Because I ask, if a father of a family whose slave murdered his children, killed his wife, burned his house, did not put such a slave to death and the worst torment - would he be regarded lenient and merciful, or, on the contrary, inhuman and cruel?"61 In this call for solidarity among slave owners Cicero makes clearly noticeable references, as if transferring them from the early period of the Stoic doctrine, to philosophical statements ,for elitist solidarity of materially independent [...] slave owners for whom the lower classes of society, the masses [...] had to be

57 Arystoteles, Polityka 1255 a, Op. cit.; I. Bieżuńska- Małowist, Niewolnictwo, Op. cit., p. 224.

58 M.T. Cicero, De prov.consul. 5,10 „Iam vero publicanos miseros (me etiam miserum illorum ita de me meritorum miseriis ac dolore!) tradidit in servitutem Iudaeis et Syris, nationibus natis servituti (...)”; vide VI Philipp. 7,19: „ Populum Romanum servire fas non est, quem di immortales omnibus gentibus imperare voluerunt"; M.T. Cyceron, Filipiki. Mowy przeciwko Markowi Antoniuszowi. (In Marcum Antonium orationes Philippicae), translated by K. Ekes, Warszawa 2002, Prószyński i S-ka; M.T. Cicero, Tusculanae disputationes 3,22,54, Op. cit., p. 137.

59 M.T. Cicero, Tusculanae disputationes 3,22,54, Op. cit., p. 137.

60 M.T. Cicero, I In Catilinam, in: Orationes, translated by St. Kołodziejczyk, in: Mowy, Kęty 2013, Wydawnictwo Marek Derewiecki, p. 39.

${ }^{61}$ M.T. Cicero, IV In Catilinam 6,12. „Etenim quaero, si quis pater familias liberis suis a servo interfectis, uxore occisa, incensa domo supplicium de servo non quam acerbissumum sumpserit, utrum is clemens ac misericors an inhumanissimus et crudelissimus esse videatur. Mihi vero inportunus ac ferreus, qui non dolore et cruciatu nocentis suum dolorem cruciatumque lenierit." Op. cit., p. 71. 
the least capable of independent social existence." ${ }^{12}$ This undoubtedly meant the acceptance of the existing socio-political system. - Although this view of the first Stoics was softened later, especially in Roman Stoicism, it echoed in Cicero's speech against Catiline.

Cicero's views on the issue of slavery as a social phenomenon, presented in the above-mentioned works or speeches, in particular regarding the issue of punishing slaves, „keeping a tight rein on them,” or „destiny by nature for the best to rule others, and with a great benefit for weaker beings", are contradictory to Cicero's statements included in the analysed excerpts from De officiis, or in the cited fragments of the first book of De legibus, but also in Cicero's correspondence, which is an important source of analysis of this issue.

\section{M.T. Cicero's letters as "the windows of his soul”, allowing the glimpse into his inner world}

If we want to talk about Cicero's views on slaves, and in particular to assess his attitude to them on the basis of epistolography, then we must separate the correspondence carried on by him into two categories. The first one consisted of his letters to the slave called Tiro, in which we find Cicero's cordial attitude towards his slave and the correspondence to Cicero's family, in which Cicero repeatedly speaks favourably about Tiro, who was later to become a freedman. The other category includes letters Cicero wrote to his family, or Atticus, in which there are various mentions about other slaves belonging to familia urbana, who however, performed various duties and did not have such a position as Tiro did.

The analysis of letters written by Cicero to Tiro, who is his secretary, supervising the rewriting of his works, allows us, above all, to notice the special tone of the letters, full of concern for the slave's health; this tone, far removed from the relationship between the master and the slave prevalent in ancient times. It should be interpreted as friendly and cordial. It should be noted that all the correspondence of Cicero with his slave and then the freedman concerns primarily the state of Tiro's health, concerned with the periodic illnesses of the slave. These circumstances are the central theme of the letters. Out of 27 letters written to Tiro by Cicero, only four (XVI, 10; XVI, 13; XVI, 14; XVI, 15)

62 J. Legowicz, Historia filozofii starożytnej Grecji i Rzymu, Warszawa 1986, PWN, pp. 369-370. 
are addressed to Tiro, who is still a slave, while the others to Tiro as a freedman. These letters are from April $53 \mathrm{BC}$, when, during a trip from Rome to the estate in Cumae, the slave fell ill, as a result of which he stayed on the estate in Formiae. It is from Cumae that Cicero will write four letters to Tiro within a week. ${ }^{63}$ Close attention should be paid the letter of 1oth April 53 BC, in which Cicero writes: "I will think that I have received the most beautiful gift from you if I see you in good health; (...) if you love me, try to get better, and when you gain strength, come back to us." ${ }^{64}$ If in this letter we notice sincere concern and anxiety for the health of his slave, then he is even more clearly marked in the next letter (XVI, 14), in which Cicero speaks of his anxiety caused by the lack of news from the slave caused by the fact that messenger Andricus was late with the letter; he notes that he cannot read anything until he sees Tiro. ${ }^{65}$ The letter ends with an unusually warm sentence in which you can see a cordial friendship: "Save yourself for me". In another letter of 12th April (XVI, 15), evidently worried, Cicero writes to Tiro: "Your health gives me constant anxiety (...) take care of yourself as much as you can!"

The relapses of the slave's illness will occur several times, and information about them will be found in the next letters of Cicero to Tiro, who will already be a freedman. The liberation took place in the last days of April or in the first days of May 53 BC.

This close relationship that existed between Cicero and his slave, which resulted in Tiro's liberation, is also found in a letter to his brother Quintus when he writes: "(...)"nobis amicum quam servum esse maluisti." ${ }^{67}$

Tiro's liberation did not change the character and tone of Cicero's letters to the former slave. Therefore, the following quote from the letter of 7 th November $50 \mathrm{BC}$, written from Leukas, should be cited to confirm the words about Cicero's extremely friendly attitude towards the former slave: "I would like you to know, my Tiro, that all those who love me, love you at the same time, and as for me and you, the most important thing is that you are healthy

${ }^{63}$ B. Bolz, Niewolnicy w pismach Cycerona, Op. cit., p. 41.

64

M.T. Cicero, Epistulae Ad Fam. XVI, 13

M.T. Cicero, Epistulae Ad Fam. XVI, 14.

${ }^{66}$ M.T. Cicero, Epistulae Ad.Fam. XVI, 15.

${ }^{67}$ M.T. Cicero, Epistulae Ad Fam. XVI, 16,1. 
and many others take care of the same thing, too." ${ }^{38}$ In his letter, Cicero emphasizes the importance of Tiro for his writing activity, but also for private matters, when he says: "Your services for me are countless: at home, in court of law, in Rome, in the province, in private and public matters, in my classes and literary works." ${ }^{19}$ Cicero expresses anxiety and concern about Tiro's health. ${ }^{70}$ While analysing Cicero's letter we must pay special attention to a special style indicating the connection between Cicero and Tiro, which was not only a cordial friendship, but also an intimacy. The very beginning of the letter, in which Cicero sends heartfelt greetings to "my dear Tiro, son, brother and nephew”, indicates the attitude of the patron towards the former slave, the attitude that was unprecedented in the slave system in ancient Rome. The same concern about Tiro's health is noticeable in the following letters: from 12th January $49 \mathrm{BC}$, when he recommends that the freedman should take care of himself and go on a journey only when he recovers, as well as in the letter of 27 th July $45 \mathrm{BC}$ in the words full of friendship Cicero writes: „I expect, judging from your letter, that you are better; (...) So remember please to take care of your health in every way (...) you are with me if you take care of yourself." ${ }^{\prime 1}$ This letter also includes Cicero's affectionate feelings for Tiro, which is highlighted by the ending of the letter. ${ }^{72}$

If we see the cordiality in Cicero's letters shown to the slave and then to the freedman, the thought arises that such cordiality remained within the family and in Cicero's letters. The existing slave system as well as the correctness established within the state did not allow public display of cordiality, or any mention of Tiro even in letters to Atticus, with whom Cicero had a very lively correspondence. In his letters to Atticus, he mentions Tiro only twice. This occurs in a letter from July 50 BC (VI, 7,2), in which he writes: „Tiro ad te dedisset litteras, nisi eum graviter aegrum Issi reliquissem. sed nuntiant melius esse. ego tamen angor;

${ }^{68}$ M.T. Cicero, Epistulae Ad Fam. XVI, 4, Wybór Listów, translated by G. Pianko, prepared by M. Plezia, Wrocław 2004, Zakład Narodowy im. Ossolińskich, p. 275.

${ }^{69}$ M.T. Cicero, Epistulae Ad Fam. XVI, 4,3; XVI, 4,1-3, p. 275.

70 Tiro accompanied Cicero to Cilicia (letter 83 ), where, shortly before his return, he became seriously ill (letter 89) and had to stay in Patrai. A footnote to M.T. Cycero, Wybór listów, Op. cit., p. 274.

${ }^{71}$ M.T. Cicero, Epistulae Ad Fam. XVI, 22,1, Op. cit., p. 368.

72 M.T. Cicero, Epistulae Ad Fam. XVI, 22,2, Op. cit., p. 369. 
nihil enim illo adulescente castius, nihil diligentius”. („Tiro would write to you if I did not leave him seriously ill in Issos") and in letter VII, 2,3. ${ }^{73}$

We also see this open confession of a friendship with slaves in Cicero's letter to Atticus when he talks about sadness caused by the death of his reader Sositheus.

M.T. Cicero, Ad Att. I,12,4: „When I was writing this letter, I was very upset. Because a nice boy died, my reader Sositheus; this worried me more than the slave's death should sadden. ${ }^{74}$

No matter what these words say about the humane treatment of the slave, one may wonder whether Cicero's emotional and mental state caused by his slave's death was a reflection of his own beliefs, or, as J. Justyński notices, „it was a nod towards the custom of the ancestors (mos maiorum), the cultivation of which Cicero considered to be his duty." ${ }^{35}$

However, if we assume that: “(...) letters are like windows of the soul, which the author involuntarily opens, thus allowing others look inside his/her own world"76 , it is difficult not to acknowledge that in personal letters to his family, his friends or Tiro, Cicero did not express his real beliefs and thoughts and that his humanism commanded him to see a human being in a slave, when he excused himself before Atticus for his delayed arrival caused by his slaves' illness: „When I know the day of my arrival, I will notify you. I have to wait for things to come from Anagni, besides, my servants are ill (...)"'77; in another letter to Atticus he writes about a letter from him which his slaves lost. He does not mention anything about punishing them, he says that he only limited himself to shouting at them..$^{78}$ In this Cicero's approach to slaves, we find the observance of the duties, recommended in De officiis, which are firmly founded on the virtue manifesting itself in greatness and perfection of the spirit and in restraint and moderation, modesty, temperance and self-control, because, as he said: "Benefit can be found only in glorious, fair and

${ }^{73}$ M.T. Cicero, Epistulae Ad Att. VI, 7, 2; VII, 2, 3, translated by G. Pianko, Op. cit., p. 268.

74 M.T. Cicero, Epist. Ad Att. I, 12, 4, 1 January 61 r. p.n.e., p. 20.

75 J. Justyński, Listy polityczne Cycerona, Warszawa 1970, Instytut Wydawniczy PAX, p. 154.

76 L. Siemieński, Bibliografia F. Morawskiego, „Pamiętnik Literacki” vol. second, Poznań 1867, p. 11; vide J. Justyński, Listy polityczne..., Op. cit., pp. 10, 207, 266.

${ }_{77}$ M.T. Cicero, Epistulae Ad Att. XVI, 8,1, Puteolanum, 2 November 44r., Op. cit., p. 389.

${ }^{78}$ M.T. Cicero, Epistulae Ad Att. 1,8,1. 
virtuous acts", deeds worthy of a brave person, therefore they should be given priority. ${ }^{79}$

Thus, if we see Cicero's cordiality shown in the letters to Tiro, as well as his forbearance for the various neglects that slaves committed, and finally the care given to the sick slaves, then all these manifestations make us believe that Cicero certainly had a kind attitude towards specific slaves, known to him, or to the ones who performed personal duties, undoubtedly this attitude being limited to some extent by taking care to preserve the old Roman tradition and to maintain the proper reputation in the circles of conservative aristocracy. ${ }^{80}$

Nevertheless, it must be stated that it is difficult not to see a humanist in $\mathrm{Ci}$ cero because his humanism is perceived through his letters and works; it is evident in his approach to the issue of captivity and slavery, as well as in pointing to the need for proper treatment of subjects, which is expressed in the following words, included in De officiis: „However, with all the means to preserve and maintain power, there is nothing more advantageous than securing love of the general public and nothing more harmful than arousing fear." ${ }^{81}$ And if in his philosophical and literary works Cicero avoids using such words as: "thing", "animate tool" or ",endowed with a voice" indicates a Cicero's cautious departure from the widely-held, conservative views on slaves adopted in Rome, at the same time we can not fail to see that in legal trials he used the concepts and conclusions adopted in legal practice ${ }^{82}$; that he spared no effort in hurling insults at the slaves in political fights, but it seems that he always saw human beings in them.

However, despite perceived humanism, it must be pointed out that in his letters we can also see considerable caution exercised in the words used to talk about slaves. He gave a severe opinion about his brother Quintus's behaviour towards the trusted slave called Statius, who played an influential role accompanying Quintus in Asia. When Cicero writes to Atticus (June or early July 59 BC), Statius has already been liberated, which causes Cicero's great dissatisfaction: "I am very worried about Statius's liberation", and in his next letter (mid-July $59 \mathrm{BC}$ ) he definitely gives vent to his bitterness over this, stating that there are many things that he is worried by: "Both disturbances in the state and the

${ }^{79}$ M.T. Cicero, De officiis 3,27,28; 100-102, Op. cit., pp. 526-527.

80 M.T Cicero, Epistulae Ad Fam. XVI, 4, Op. cit., p. 275; J. Justyński, Listy polityczne..., Op. cit., p. 157.

${ }^{81}$ M.T. Cicero, De officiis 2,7,23, Op. cit., p. 427.

${ }^{82}$ M.T. Cicero, B. Bolz, Niewolnicy w pismach Cycerona, Op. cit., p. 92. 
dangers that personally threaten me, and there are thousands of them; but there is no greater pain for me than Statius's liberation." ${ }^{33}$ This Cicero's dissatisfaction caused by his brother's freedman is evident in Cicero's generally negative attitude towards the liberation of slaves, in the advice given to his brother about keeping slaves under strict discipline and in forbidding them to attend to official matters, with the exception of using them to take care of private matters. Even freedmen - as he wrote to his brother - should not be allowed to exercise too much influence because it is contrary to the prevailing customs and arouses dissatisfaction among representatives of the familial aristocracy. ${ }^{84}$ If Cicero does not spare Quintus his comments in the name of mos maiorum when he notices that in the familia of his brother, who was the pro-praetor for Asia, there are customs that undermine his brother's reputation among slaves, and consequently in the Roman public opinion, largely due to the case of the freedman Statius ${ }^{85}$, he is capable of circumventing the accepted rules concerning the relations with slaves on the condition that they were slaves of famous people, for instance, Alexis, who was Atticus's slave, for whom Cicero showed consideration, similar to that of Tiro, in a letter to Atticus (Ad Att. XII, 10): "Alexin vero curemus, imaginem Tironis, quem aegrum Romam remisi", or Eutychides, who helped Cicero during his exile and whom he calls meus amicus Eutychides (Ad Att.V, 9,1; Ad Att. IV, 15,1). This distinctive attitude towards slaves who had a special position in the familia of his friends, or slaves who helped him or his family during his exile, stems from the Cicero's character and from his very diverse look at the issue of slavery and his slaves, his flexibility in his views on slavery, but also in his views on the doctrines of various philosophical schools.

Although in his works we see the stoic ideas about the equality of all people and about humanity, Cicero divided slaves into two categories: those who were useful to him, who, additionally, had a special position in his familia and who had special features distinguishing them from ordinary slaves, which enabled

83

M.T. Cicero, Epistulae Ad Att. II, 18,4; II, 19,1, Op. cit., p. 83.

O. Nowak, Myśl polityczno-prawna i społeczna M.T. Cycerona, w świetle jego twórczości i działalności politycznej, jako odzwierciedlenie idei schyłku republiki rzymskiej - master dissertation, 1911, p. 55; Ad Quintus 1,2,1; 1,1,6; J. Justyński, Listy polityczne..., Op. cit., pp. 145 and 154-155; W. Kornatowski, Doktryna polityczna Cycerona jako doktryna czasów przełomowych, „Życie i Myśl” (1965) nr 3-4 and 5-6; K. Kumaniecki, Cyceron i jego współcześni, Warszawa 1954, Czytelnik, pp. 8-9.

${ }^{85}$ M.T. Cicero, Epistulae Ad Qu. fr. 1 1,17; 1 2,1; B. Bolz, Niewolnicy w pismach Cycerona, Op. cit., p. 48. 
him to see humans or friends in them, and those who, like a object, like a tool (however, as already mentioned, he did not use such terms in his writings and in his court speeches), were useful only for physical work. Therefore, it should be assumed that Cicero's views on slavery also contain numerous contradictions, hesitations and compromises. Although, in the above-mentioned work titled De officiis Cicero expresses compassion towards the rank of slaves, „afflicted by the hardest plight", he was not inclined to liberate them. From Cicero's point of view, liberation was an act that should be only performed for the benefit of the most distinguished slaves, it was to be an incentive, and then a form of reward for faithful service. However, he certainly placed slaves much higher in the social hierarchy than proletarians, whom he described as: "social scum, rallying blood-sucker of the treasury, the wretched and starveling mob" ${ }^{\text {, }}$, which was undoubtedly influenced by the criteria of the usefulness of this social rank for the Roman Republic, because, if slaves were an indispensable element for the economy of the country, proletarians, however free, were economically unproductive, or even harmful as political issues are concerned. Therefore, according to Cicero, the proletarian class should be removed and settled at the ends of the Empire. ${ }^{87}$ Although Cicero, despite numerous views on slaves and proletarians, never formulated a general assessment that would encompass both slaves and proletarians, he was aware that these were the two social classes that could always be manipulated in the Roman state.

It should, therefore, be assumed that Cicero's views on slavery hide many contradictions, hesitations and compromises.

This indecisiveness about the assessment of slavery, this lack of Cicero's uniform view and his unequivocal assessment of this social rank certainly resulted from the necessity to choose between utilitas and humanitas, which is perfectly illustrated by the following statement by Cicero, in which he cites the Sixth Book of Hekaton on duties and whose quintessence is the statement that „,...) something else is motivated by material considerations and something else is motivated by the consideration for humanity".

M.T. Cicero, De officiis 3,23,89

„Plenus est sextus liber de officiis Hecatonis talium quaestionum, sitne boni viri in maxima caritate annonae familiam non alere. In utramque partem disputat,

${ }^{86}$ M.T. Cicero, Epistulae Ad Att. 1,16,11, p. 37; Ad Att. 2,16,1, pp. 75-76; J. Justyński, Listy..., Op. cit., p. 163.

${ }^{87}$ M.T. Cicero, Epistulae Ad Att. 1,19,4. 
sed tamen ad extremum utilitate, ut putat, officium dirigit magis quam humanitate. Quaerit, si in mari iactura facienda sit, equine pretiosi potius iacturam faciat an servuli vilis. Hic alio res familiaris, alio ducit humanitas." ${ }^{38}$

The majority of Rome's intellectual elite approached the issue of slavery in a similar way, showing pity or compassion towards their slaves, and yet they were often indifferent to other people's slaves, making a choice between what obligations required and what benefits called for. If, while defending the people of the province of Sicily, Cicero emphasizes his humanism, then it is also noticeable in the cited Cicero's letters, which prove that he treated slaves in a humane way and, what is more, recognized them as humans ${ }^{89}$, at least those with whom he came into contact, or those from whom he obtained help, or when a slave was simply necessary to settle all matters, as in the case of Tiro, at the same time in a very matter-of-fact way he presents his reports from the period of fights with the highlanders of Amman and the Free Cylians living on the border between Cilicia and Syria and not recognizing the Roman sovereignty. In these reports included in a letter to Atticus, Cicero describes the methods he uses to pacify the conquered areas, the way the most resistant enemies are killed and the sale of some of them into slavery and the sale of prisoners of war into slavery after Cicero captured the city of Pindenissus:

M.T. Cicero, Epistulae Ad Att. 5,20,5

"And I went to Pindenissus, a very fortified city of Free Cylians, which, as you remember, has always been under arms. (...) I surrounded the city with a rampart and a ditch; for the siege I used a huge embankment, sheds, a high tower and a large number of propelling machines and archers; I did the work with great effort and preparations (...). Prisoners are being sold on the third day of Saturnalia, when I am writing this, the sum from the sale before my tribunal reaches 12 million sestercia." ${ }^{\prime 90}$

Being the owner of numerous estates, Cicero was also interested in acquiring more slaves who were needed in his rural estates and houses in the capital city. We receive information about the needs in this respect from a letter to his brother Quintus, who acted as Caesar's legate in the land of Nervii in Gaul,

${ }^{88}$ M.T. Cicero, De officiis 3, 23, 89, Pisma filozoficzne, Op. cit., p. 520.

89 M.T. Cicero, De officiis 3,23,89, p. 520 - philosophical analysis utilitas and humanitas; Ad Att.1,12,4; J. Justyński, Listy. polityczne..., Op. cit., p. 154.

${ }^{90}$ M.T. Cicero, Epistulae Ad Att. 5,20,5, Op. cit., pp. 222-223; J. Justyński, Listy..., Op. cit., pp. $146-147$. 
in which he writes that he is grateful for the promise of sending slaves because he desperately needs them, „both in Rome and on landed estates”, ${ }^{\text {, which would }}$ indicate that he needed rather unskilled slaves, which is confirmed by the letter to Atticus, in which he reflects on the purpose of Caesar's expedition to Britain and raises the issue that the only gain from the expedition will be ordinary slaves, "-who are not familiar with literature or with music." ${ }^{92}$

Based on the analysis of Cicero's works and epistolography, it should be acknowledged that in practice Cicero's instructions boiled down to recommending forgiveness and self-control in relations with slaves, limiting their activities to private matters, eliminating them from political games and seeing humans in them. During the civil war between Caesar and Pompeius, in Cicero's correspondence there are fears that there might be more serious riots started by slaves. Cicero also emphasized the phenomenon of the exploiting slaves by political parties, which is, inter alia, noticeable in Catilinarian Orations [the Polish title: Mowy przeciwko Katylinie]: "I ordered to bring Volturius himself, without the Gauls. (...) Then he (...) said that he had orders from Publius Lentulus and a letter from Catiline to use slaves to help him and to stand with the army outside the city as soon as possible." ${ }^{93}$ Also in his last speech, Cicero returns to the accusation made at the beginning of Speech One $(\mathrm{I}, 11,27)$ about inciting slaves to rebel ${ }^{94}$, putting this crime on an equal footing with collusions with an external enemy, saying: "Allobroges are being stirred up, slaves are being incited to rebel." ${ }^{95} \mathrm{He}$ also pointed out that not only political ideas and the hope to be liberated, but also tangible material benefits were an important stimulus which mobilized slaves to fight. Cicero's attitude to the participation of slaves in political life was certainly conditioned by his own socio-political position. Therefore, Cicero strongly criticized those among the slaves who supported the actions of Populares, but praised the use of them by Optimates in justified cases. We also see this position in the Fourth Speech against Catiline, when Cicero calls on all people, all social ranks, all spheres, of all ages to defend the homeland, he also refers to slaves, saying: “There is no slave (...) who would not be shaken by citizens' cit., p. 52.

M.T. Cicero, Epistulae Ad Qu. fr. III, 7,4; B. Bolz, Niewolnicy w pismach Cycerona, Op.

92

M.T. Cicero, Epistulae Ad Att. IV, 16,7; B. Bolz, Niewolnicy w pismach..., Op. cit., p. 52.

93

M.T. Cicero, 3 In Catillinam, Op. cit., p. 56.

94

M.T. Cicero, I In Catillinam 11,27, Op. cit., p. 39.

95 M.T. Cicero, IV In Catillinam 2,4, Op. cit., p. 68. 
audacity, (...) who would not want to contribute to our joint salvation." ${ }^{96}$ As for the escape of slaves, we also see Cicero's firm position, because he, as the owner of numerous possessions and slaves belonging to familia rustica, and familia urbana, shared the opinion of all slave owners that the escape threatened their property because it reduced the workforce and, in the case of capturing the slave, it reduced his/her market value. This position is expressed by Cicero in De officiis when he discusses the principle of bona fides and notices that: “(...) no approach on the part of the seller while selling slaves is allowed. Whoever had the knowledge of the slave's health condition, his tendency to escape and steal, bears responsibility based on the edict of Aediles." ${ }^{\text {97 }}$

While analysing Cicero's statements included in both his works and in letters written to his family and friends, we should take into account that Cicero's humanism was enclosed in a defined framework which was not only confined by philosophy, but rather confined by him alone, however much this philosophy shaped him. Although none of Cicero's philosophical writings is specially devoted to aesthetics, many of them contain a number of comments in this regard, particularly Libri Academici, Tusculanae disputationes, De officiis, De oratore and Orator, ,which provides the history of aesthetics with a new perspective on the concept of aesthetics that forms part of the stoic ideology." ${ }^{\text {98 }}$ When perceiving Cicero from the angle of aesthetics, one should pay attention to his attitude as a humanist, to the method of executing the death penalty, which already existed in the republic in the form of damnatio ad bestias, by fighting wild animals, which involved sending deserters or fugitive slaves to be devoured by animals. That method of punishment became widespread during the Principate era. ${ }^{99}$ If, during the republic, venationes were not yet a place of mass slaughter, and Cicero himself rather condemned the cruelty of gladiatorial fights, then we already see Cicero's opposition to the idea of people fighting wild animals when he writes,

${ }^{96}$ M.T. Cicero, IV In Catillinam 8,16, Op. cit., p. 74.

97

M.T. Cicero, De officiis 3,17,71, Op. cit., p. 508.

98 Wł. Tatarkiewicz, Historia estetyki. Starożytność, Warszawa 1985, Wydawnictwo Arkady, p. 194.

(D. 48,19,28 pr.); E. Żak, Prawnicy rzymscy o sposobach wykonania kary śmierci, in: H. Kowalski, M. Kuryłowicz, Kara śmierci w starożytnym Rzymie, Lublin 1996, Wydawnictwo UMCS, p. 110; J.A. Crook, Law and Life of Rome, London 1967, new edn. 1984, Thames and Hudson, pp. 273 and n.; D. Słapek, Damnatio ad bestias w rozwoju venationes okresu republiki rzymskiej, in: H. Kowalski, M. Kuryłowicz, Kara śmierci w starożytnym Rzymie, Lublin 1996, Wydawnictwo UMCS, pp. 129, 136. 
in a letter to Marcus Marius, about the games organized by Pompeius on the occasion of consecration of the theatre and the temple of Vesta that he had built:

M.T. Cicero, Ad Fam. VII, 1.

“(...) Can cultured people, after all, find pleasure in the fact that a weak person will be torn to pieces by a powerful beast or that a wonderful animal will be pierced with a javelin. The last day was dedicated for elephants: they aroused great admiration among the common people, but this sight did not give any pleasure; on the contrary, it even evoked some pity and the impression that this creature had something in common with humankind." ${ }^{\prime 100}$

For an aesthete, the sight of a fight between a human and elephant was incomprehensible and brutal, where the cruelty of the fight triggered humanitas in Cicero, not only in relation to the human-criminal or a slave, but also in relation to the animal, which gave the impression that "this creature has something to do with humankind." ${ }^{101}$ During the Principate, Cicero's description will be referred to, with words full of explicit criticism, by Seneca in De brevitate vitae, who writes that: “(...) Pompeius first organized a fight in the circus, releasing eighteen elephants, as if during a regular battle, to attack the crowds of villains. (...)"102

\section{The reflection of Terence's words „Homo sum humani nihil a me alienum puto" in M.T. Cicero's views on slavery and slaves}

From the analysis of works, speeches and correspondence, we receive an image of a philosopher-man, who gives us various views on, thoughts about and insights into the phenomenon of slavery in Rome. Hence, it is difficult to specify Cicero's unequivocal position on the discussed issue, as well as give a clear assessment of Cicero's views on this subject. Let us look at the views of researchers of this social phenomenon and the assessment of Cicero's attitude to the issue

100 M.T. Cicero, Epistulae Ciceronis (Wybór listów), Ad Fam. VII, 1,3, Op. cit., pp. 53-156; M.T. Cicero, Tusculanae disputationes 2,17,41, Op. cit., p. 95.

101 M.T. Cicero, Epistulae Ciceronis, Ad Fam. VII, 1,3, Op. cit., pp. 153-156; M.T. Cicero, Rozmowy tuskulańskie II, 17,41, Op. cit., p. 95.

${ }^{102}$ L.A. Seneka, Epistulae morales ad Lucillium, VII, 3, 5, Op. cit.; L.A. Seneka, Dialogorum: De brevitate vitae, XIII, p. 124, translated by L. Joachimowicz. Dialogi, Warszawa 2001, Wydawnictwo De Agostini, and Instytut Wydawniczy PAX. 
of slavery. If, according to J. Marguardt, Cicero favoured the views of Aristotle $^{103}$, then, according to J. Justyński, who emphasizes the important role of mos maiorum in Cicero's views, one should rather be inclined to accept the opinion expressed by T. Sinka ${ }^{104}$, who thought that "Cicero was wavering between the stoic demand for the fundamental equality of all people", and Aristotle's view that „slavery is a natural necessity”. Cited by B. Bolz - M.Th. Hanquet expressed the view that "Cicero's real opinion on slavery boils down to expressing mos maiorum” in various perspectives. In turn, B. Bolz, referred to in this article, is of the opinion that an attempt to classify Cicero, who is an excellent speaker and thinker, into a certain category may prove to be unreliable. ${ }^{105}$

In conclusion to the statements about slavery and slaves cited above, and above all, to that of M.T. Cicero, the statements included in the philosopher's works, speeches and the discussed-above letters, which alternately cause us to accept and admire Cicero's statements, and then to feel disappointed with and criticise his views, it should be noted that the times when Mark Tullius Cicero lived are a period of history which is deeply rooted in, or even dependent on the slave system, so it is difficult to expect a clear position on slavery and slaves in Cicero's views, given, in particular, Cicero's characteristic lack of a clear position in philosophical views on various issues, because, as Cicero himself says in Tusculanae disputationes: "Let everyone defend their opinion; because courts of law are free. As far as I am concerned, without being shy, according to my custom, without reference to the rules of any particular school, I will always search in every single thing for what is most similar the truth."106 It should, therefore, be recognized that Cicero's humanism, firmly embedded in the Stoic doctrine and in natural law, as the core of this doctrine, is expressed in the fullest way in his definition of justice: ,iustitia, in qua virtutis splendor est maximus, ex qua viri boni nominantur, et huic coniuncta beneficentia, quam eandem vel benignitatem vel liberalitatem appellari licet." ${ }^{107}$ In defining justice, Cicero notes that it primarily requires that no one inflicts harm on another person, but reserves: unless someone would be forcet to do it due to the harm inflicted on him/her.

103 J. Marquardt, Das Privatleben der Romer, vol. first, Berlin 1926, p. 191.

104 J. Justyński, Listy polityczne..., Op. cit., p. 158; T. Sinko, Historyczna rola stoicyzmu, „Przegląd Powszechny” (1935), vol. 204, p. 332.

105 B. Boz, Niewolnicy w pismach Cycerona, Op. cit., p. 90.

106 M.T. Cicero, Tusculanae disputationes 4,4, Op. cit., p. 158.

107 M.T. Cicero, De officiis 1,7,20, Op. cit., p. 338-337. 
According to Cicero, the basis of such justice is reliability, that is, stability and integrity in all concluded contracts and promises. It is the stoic ideal of justice that should guide everyone, which means not only the rank of Nobiles, but it should also be applied to the lower social ranks.

Cicero connects these issues with their opposite, namely injustice and harm, failure in fulfilling the obligation to defend the ill-treated, injustice towards people of the lowest rank, namely slaves. ${ }^{108}$ If we find such words in Cicero's views, then it should be recognized that they also include the words of the poet Terence: "Homo sum, humani nihil a me alienum puto", because for a philosopher, a follower of the Stoic doctrine and principles of natural law, such qualities as friendship, compassion, justice, fear of slavery, exile, and loss of homeland, which constitute humanity, were not foreign to him. If Cicero's humanism allowed him to see a human being in a slave, then it was only a forecast of the views of the philosophers of the new era, especially the moral philosophy of Seneca and Marcus Aurelius, an outline of new doctrinal formulations. ${ }^{109}$ These, in a far more consistent way, defended the slave, although they did not contribute to the abolition of the slave system, because even in Seneca’s works, who said: “(...) Sic cum inferiore vivas, quemadmodum tecum superiorem velis vivere" ${ }^{\prime 10}$, we see the acceptance of the slave system expressed in his statement that he does not intend to destroy existing orders, but, on the contrary, his intention is to ensure tranquillum otium and securitas publica. ${ }^{11}$

If, in the times that followed the fall of the Roman Republic, we see the activities of Roman emperors, the intellectual elite of Rome, philosophers, and, to a significant extent, Roman jurists who very often adhere to the stoic doctrine; the activities that aim at improving the socio-economic and legal situation of slaves, it would, however, be an inaccuracy to attribute the only merits in the humanitarian treatment of slaves solely to the Stoic doctrine, or, to some extent, to earlier Greek doctrines, because what was the failure in Stoicism was turned into success in the Christian religion. If the Stoics attached importance to wisdom which allowed to achieve true freedom, understood as freedom from passion and desire, then „for Christians, the essence of freedom was freedom

108 M.T. Cicero, De officiis 1,13,41, Op. cit., p. 349.

109

B. Bolz, Niewolnicy w pismach Cycerona, Op. cit., p. 92.

110 L.A. Seneka, Epistulae morales..., 5,47,11, Op. cit., pp. 430-431 „(...) Treat the weaker as you would like the stronger to treat you."

111 L.A. Seneka, Epistulae morales ad Lucilium, Op. cit., p. 73. 
from sin and achieving salvation." ${ }^{112}$ Therefore, in both the Stoic and Christian doctrine we will not find postulates to abolish the institution of slavery, which was recognized and accepted in the same way as the state and its legal institutions. Nevertheless, this stoic humanitarian approach to the institution of slavery can be found in Christian teachings that had an influence on alleviating the social and legal position of slaves as long as slavery existeds.

\section{Bibliography}

Afer P.T., Samoudręczyciel, verse 77, in: M.T. Cicero, De legibus, translated by I. Żółtowska. O państwie, O prawach, Warszawa 2010, Hachette.

Arystoteles, Retoryka, translated by W. Madyda, Wrocław 2000, Zakład Narodowy im. Ossolińskich.

Arystoteles, Polityka, translated by L. Piotrowicz, Wrocław 2005, Zakład Narodowy im. Ossolińskich.

Arystoteles, Etyka Nikomachejska, translated by D. Gromska, Warszawa 1982, PWN.

Bieżuńska-Małowist I., Małowist M., Niewolnictwo, Warszawa 1987, Czytelnik.

Bolz B., Niewolnicy w pismach Cycerona, Poznań 1963, PAN.

Carcopino J., Życie codzienne w Rzymie w okresie rozkwitu Cesarstwa, translated by Maria Pąkcińska, Warszawa 1966, PIW.

Cicero M.T., De natura deorum. De divinatione. De fato, translated by W. Kornatowski, Pisma filozoficzne: O naturze bogów. O wróżbiarstwe. O przeznaczeniu, first vol., Warszawa 1960, PWN.

Cicero M.T., De re publica. De legibus. De officiis. De virtutibus, translated by W. Kornatowski, Pisma filozoficzne: O państwie. O prawach. O powinnościach. O cnotach, second vol., Warszawa 1960, PWN.

Cicero M.T., De re publica. De legibus, translated by I. Żółtowska, O państwie. O prawach, Warszawa 2010, Wydawnictwo Hachette.

Cicero M.T., Tusculanae disputationes, translated by E.Rykaczewski, Rozmowy tuskulańskie, Warszawa 2009, Wydawnictwo Hachette.

Cyceron M.T., Filipiki. Mowy przeciwko Markowi Antoniuszowi. (In Marcum Antonium orationes Philippicae), translated by K. Ekes, Warszawa 2002, Prószyński i S-ka.

Cicero M.T., Orationes: In Catilinam, translated by St. Kołodziejczyk, Mowy, Kęty 2013, Wydawnictwo Marek Derewiecki.

12 I. Bieżuńska-Małowist, M. Małowist, Niewolnictwo, Op. cit., p. 232; J. Carcopino, Życie codzienne w Rzymie w okresie rozkwitu Cesarstwa, translated by M. Pąkcińska, Warszawa 1966, PIW. 
Cicero M.T., Epistulae Ciceronis, translated by G. Pianko, prepared by M. Plezia, Wybór Listów, second edition, Wrocław 2004, Zakład Narodowy im. Ossolińskich.

Crook J.A., Law and Life of Rome, London 1967, new edn. 1984, Thames and Hudson.

Digesta Iustiniani, edited by T. Palmirski, Kraków 2013, 2014, Wydawnictwo Poligrafia Salezjańska.

Digesta Iustiniani, libri 1-5, translated by B. Szolc-Nartowski, Warszawa 2007, Oficyna Wydawnicza Wyższej Szkoły Handlu i Prawa im. R. Łazarskiego.

Finley H., Ancien Slavery and Modern Ideology, New York 1980, Viking Press.

Gai Institutiones, translated by C. Kunderewicz, Warszawa 1982, PWN.

Institutiones Iustiniani, translated by C. Kunderewicz, Warszawa 1986, PWN.

Jarzębiak J., Jak możliwa jest wolność? Odpowiedź Chryzypa z Soloi, „Przegląd FilozoficznyNowa Seria” R. 14 (2005) nr 2 (54).

Justyński J., Listy polityczne Cycerona, Warszawa 1970, Instytut Wydawniczy PAX.

Kolańczyk K., Prawo rzymskie, updated by J. Kodrębski, Warszawa 2007, Lexis Nexis.

Kornatowski W., Zarys dziejów myśli politycznej starożytności, Warszawa 1968. Instytut Wydawniczy PAX.

Kornatowski W., Doktryna polityczna Cycerona jako doktryna czasów przełomowych, „Życie i Myśl” (1965) nr 3-4 and 5-6.

Kumaniecki K., Cyceron i jego współcześni, Warszawa 1954, Czytelnik.

Laertios D., Żywoty i poglądy słynnych filozofów, translated by I. Krońska, Warszawa 1968 - first edition, 1988 - second edition, PWN.

Legowicz J., Historia filozofii starożytnej Grecji i Rzymu, Warszawa 1986, PWN.

Łapicki B., Poglądy prawne niewolników i proletariuszy rzymskich, Łódź 1955, Zakład im. Ossolińskich, Wrocław, Łódzkie Towarzystwo Naukowe.

Marquardt J., Das Privatleben der Römer, vol. first, Berlin 1926.

May J.M., Cicero Oratory and Rhetoric, Leiden. Boston. Köln 2002, Brill,s Companion.

Morawski K., Marek Tulliusz Cicero, Życie i dzieła, in: Historia literatury rzymskiej, vol. second, Kraków 1911.

Nowak O., Myśl polityczno-prawna i społeczna M.T. Cycerona, w świetle jego twórczości i działalności politycznej, jako odzwierciedlenie idei schyłku republiki rzymskiejmaster dissertation, Toruń 1911.

Platon, Politeia, translated by W. Witwicki, Państwo, Warszawa 1999, Wydawnictwo Alfa.

Seneka L.A., Epistulae morales ad Lucillium, translated by W. Kornatowski, Listy moralne do Lucyliusza, Warszawa 1961, PWN.

Seneka L.A., Dialogorum: De brevitate vitae. De vita beata. De ira, translated by L Joachimowicz. Dialogi, Warszawa 2001, Wydawnictwo De Agostini and Instytut Wydawniczy PAX.

Sinko T., Historyczna rola stoicyzmu, „Przegląd Powszechny” vol. 204 (1935). 
Słapek D., Damnatio ad bestias w rozwoju venationes okresu republiki rzymskiej, in: H. Kowalski, M. Kuryłowicz, Kara śmierci w starożytnym Rzymie, Lublin 1996, UMCS.

Strauss L., Prawo naturalne w świetle historii, translated by T. Górski, Warszawa 1969, Instytut Wydawniczy PAX.

Tatarkiewicz Wł., Historia estetyki. Starożytność, Warszawa 1985, Wydawnictwo Arkady. Tokarczyk R., Klasycy praw natury, Lublin 2009, Wydawnictwo UMCS.

Żak E. Prawnicy rzymscy o sposobach wykonania kary śmierci w starożytnym Rzymie, in: H. Kowalski, M. Kuryłowicz, Kara śmierci w starożytnym Rzymie, Lublin 1996, UMCS. 